\title{
Environmental Scanning and Communication Technology as a Gate for Sustainable Competitive advantage of Sanitary Ware (bathtub) Suppliers in Kingdom of Saudi Arabia
}

\author{
Baha`a Abdul-Hafez Attallah Al-Nady1 (Corresponding Author), \\ Ahed Saket Al-Haraizah2, Sulieman Ibraheem Shelash Al-Hawary3 \\ 1Business Coach and Researcher, Master in E-Business, Faculty of Business, Middle East University, \\ P.O.Box 230505 Amman 11123 Jordan, bahadh@hotmail.com \\ 2 Ahed Al-Haraizah, Assistant Professor in Electronic Commerce Technology, Faculty of Business, Middle \\ East University, P.O.Box 230505 Amman 11123 Jordan email:drahed@hotmail.com, Tel: +962-779606202. \\ 3 Associate Professor of Business Management, Department of Marketing, Faculty of Business and Finance, \\ American University of Madaba, P.O.Box 2882, Amman 11821, Jordan \\ s.mohammed@aum.edu.jo,dr_sliman73@aabu.edu.jo,dr_sliman@yahoo.com
}

\begin{abstract}
Today globalization turned the world into a global village where event in one region transmits to others almost immediately. Communication technology has played big role and transformed many aspects of business; Internet is one of most important technology which has created e-commerce and a global digital economy with new opportunities. Social media such as websites Twitter, Facebook, Linkedln and Pinterest have already demonstrated their potential for getting information also mobile technology have a lot of potential for gathering information. In spite of environmental turbulence, organizations must effectively depend on scanning environment and useful communication technology for operations and survival. It is crucial for every company to analyze strengths and weaknesses of the internal and external environment to enable the business sustain and growth. Both internal and external environmental scanning is important to be conducted but basically internal scanning will be done first as it will be the ground analysis to determine further direction of an organization. Increasing risk of error, failure to analyze environment included strength and weaknesses internally, opportunities and threats externally, and inefficient of communication technology may resulting to unsustainable the business in long term. Additionally a growing number of companies in Jeddah city led to the business competition between companies that increasingly tight and competitive. This paper sought the place of environmental scanning and role of communication technology as a way for providing information helpfully and as a means of business survival and sustainable competitive advantage. In this study we will focus on Suppliers who deal with sanitary ware (Bathtub) in Jeddah city, Kingdom of Saudi Arabia. Mostly people in Jeddah City prefer to purchase from various outlets vendors / retailers who are available usually in same area, according to their convenience, preference and selection. Increases in expectations and changing culinary style of consumers make the Sanitary Ware (Bathtub) business dynamic in general. Despite the increasing interest in the area there are very little researches on sustainable competitive advantage of sanitary ware vending service in our domestic market. Keeping these conditions in view, this study tries to explore the current scenario in which Sanitary Ware (Bathtub) has become a flourishing business for a lot of Suppliers as it has been successful in attracting a large mass of customers and projects.

This study analyses environmental scanning and communication technology as a gate for sustainable competitive advantage of sanitary ware (Bathtub) in Jeddah city. The data analysis was based on 108 retailers who purchase bathtub sanitary ware from sanitary ware suppliers companies in Jeddah city, the data analysis was based on multivariate statistical techniques encompassing Factor analysis to test reliability, Percentage and frequency, descriptive analysis to describe the sample, multiple linear regressions via using SPSS analysis software. It identifies the most relevant understanding of environmental scanning and role of communication technology as agate for sustainable competitive advantage, and determines their influence in choosing of sanitary ware outlets. The results show that as environmental scanning and communication technologies (independent variables) have a positive influence on sustainable competitive advantage (dependent variable) of bathtub sanitary ware suppliers in Jeddah city.
\end{abstract}

Keywords: Environmental Scanning; Communication Technology; Sustainable Competitive Advantage; Sanitary ware (bathtub); Suppliers; Kingdom of Saudi Arabia.

\section{Council for Innovative Research}

Peer Review Research Publishing System

Journal: INTERNATION JOURNAL OF COMPUTERS AND TECHNOLOGY

Vol. 13, No. 3

editorijctonline@gmail.com

www.cirworld.com/journals 
Internet has changed working methods of most activities in the scientific, educational and commercial sectors and it affected by the development of information were Business technology in several areas such as trade, marketing, ecommerce, and e-marketing business. (Alnady Bahaa, May.2012). These sectors became obliged to deal with those concepts to survive and maintain a position in the market (Turban, 2008). Globalization is one of the factors that have altered tremendously the texture of global business environment. Consequently, there is a need for managers across the various business organizations to continually scan the environment in order to keep tab of development therefore as a means of survival (Onodugo et. al, 2013). In particular, globalization has sharpened competition and factors driving it. These factors are falling trade barriers, fast paced technological advances, declining communications and transport costs, international migration and highly mobile investment (Badrinath and Wignaraja, 2004). Creating and managing a successful business or venture requires scanning environment as well as using communication technology since it required scanning and collecting necessary data from the environment. Scanning has to do with communication technology to gathering and utilization of information concerning trends and events occurring in the internal and external environment of a firm. The business environment is so competitive that it reflects the evolving and dynamic world. It forces companies to evolve rapidly so that the company can achieve its goals and maintain the existence of performance to attain a certain level of growth. To continuously be able to meet the expectations of shareholders, management of companies should think more in longer term. In fact it means that it can be concluded that the shareholder expectations are sustainable profit. This can only be achieved if the company has a competitive advantage over its competitors (Firdaus A. and Hamsal M, 2013)

The Bathtub sanitary ware suppliers have a direct contact with the customer. So it is imperative to work closely to know about what a customer need as customer the key role in any business, without customers a business cannot exist. The customer consider as key player in Competitive advantage of sanitary ware vendors, So the customer is the major part of a business and a business succeeds only because of the customer, without the customer there is no business (Rehman et. al. 2013). Communication technology encourages sanitary ware suppliers to improve traditional channels and find alternative channels in order to improve communication and reach to maximum number of customers (retailers, end consumer) via internet and all business aspects and that help to understand environment, but the effort of environmental scanning can be the essential part to sustained competitive advantage, the factors of internal and external environmental scanning as well as technology play a big role and effect total operation of organizations. However, company's goals cannot always be achieved due to various constraints faced by, among others, unstable market demand especially for companies that have businesses on project basis, prices of raw materials, location of the company not/less strategic (Firdaus A. and Hamsal M, 2013). Environmental scanning always start with gathering information about market (customers, retailers, suppliers) and to know external opportunities and threats as well as internal strengths and weakness of organization. During environmental scanning professional manager of sanitary ware suppliers will try to know about customer expectation, sanitary ware retailers preference and sanitary ware competitors for which type of bathtub sanitary ware products they supply the market, therefore environmental scanning consider as first important dimension of strategic management for any type of business as it helps to establish correctly business and boost the business of organization. environmental scanning and communication technology are now an increasingly common management practice, when using this approach it is important to keep abreast of our market for new and upcoming players who through some variable, whether it be new technology or an aggressive advertising campaign, may become a dominant player.

At present, in Saudi Arabia housing demand is rapidly rising and with increasing purchasing power people have started taking interest in bathtub sanitary ware products. Bathtub sanitary ware demand comes from new projects and from replacement market. In Jeddah city would also soon become a hub for international sanitary ware brands. International brands such as (Roca, Wisemaker, SSWW, Potter, and Sannora) year by year plan to expand their scale of operations in Saudi Arabia Market. The expansion for international brand will be either through Brownfield expansion of their joint venture partners or through setting up Greenfield ventures. These companies will cater to the rising consumer demand within Saudi Arabia for branded and premium sanitary ware products. Saudi Arabia booming Contracting industry and growing upscale consumer market present a big opportunity for international brands. The competition between bathtub sanitary ware suppliers encourage them to distribution many bathtub sanitary ware products in Jeddah City of Saud Arabia and that create competition between sanitary ware (Bathtub - see Appendix 1.1 and 1.2) suppliers then problems appear towards increasing risk of error, failure to analyze environment included strength and weaknesses internally, opportunities and threats externally, and inefficient of communication technology may resulting to unsustainable the business in long term. Furthermore, a growing number of bathtub sanitary ware companies in Jeddah city led to the business competition between companies that increasingly tight and competitive. Hence, the researchers find that there is need to understand what we mean by environmental scanning and communication technology as a gate for sustainable competitive advantage. So, the problem statement for this study is to investigate about environmental scanning and identify the importance of internal \& external environmental scanning factors and communication technology role as a gate for sustainable competitive advantage. Therefore it has been a considerable interest in methods and concepts for studying environmental scanning and role of communication technology as a gate for sustainable competitive advantage of sanitary ware (Bathtub) suppliers in Jeddah city (Alnady Bahaa, May.2012).

\section{REVIEW OF LITERATURE}

Organizations need to think about the issue beyond the competition to capture new growth opportunities and profitability (Debi S. Saini, 2006). (West's J.J.1988) study looked at the relationship between performance and organizational strategy and environmental scanning in the US foodservice industry. Study data covered 65 firms over a period of four years (1982-1986). Findings indicate a strong positive relationship between a firm's turnover and return on assets and its strategy and environmental scanning. It was equally clear from the study that firms that engaged in scanning performed significantly better than those that did not. Another study by (Subramanian, et al. 1994) corroborated the findings above. It 
involved a survey of over six hundred hospitals who were members of American Hospital Association. Findings show that hospitals which engaged in active scanning performed significantly better than their counterparts who did not scan environment. The information obtained in the process of scanning was used mainly in the strategic planning process. (Abels, E. 2002) study findings that, environmental scanning assesses the internal strengths and weaknesses of an organization in relation to the external opportunities and threats it faces. Many researchers have acknowledged that rational data gathering activity lies at the heart of strategic decision making. According to (Daake et al. 2004), rational data gathering includes environmental scanning that involves acquiring and processing voluminous amount of information.

\subsection{Environmental Scanning}

Environmental scanning simply means a careful examination of the environment with a view to identifying opportunities to maximize and containing and minimizing threats along the lines dictated by missions and goals of a particular business (Onodugo et.al, 2013). Environmental scanning can be defined as 'the study and interpretation of the political, economic, social and technological events and trends which influence a business, an industry or even a total market (Kroon, J.1995). It emphasizes the monitoring and evaluation of external opportunities and threats in light of corporation's strength and weakness. According to (Choo,C.W. 2001) environmental scanning could range from an informal conversation with someone to a formal business research activity. (Owualah, S.I.1999) asserts that the trends that need to be scanned are rooted in five macro environments: economic, social, technological, competitive and legal environments. (Elenkov, 1997) contests that the environments that need to be scanned can be classified into two layers; the first, referred to as the task environment. Its elements include investors, employees, customers, suppliers, creditors, distributors, competitors and regulatory agencies. The second is the general environment. It refers to general environment includes socio-cultural, economic, and legal-political factors. (Turban et al, 2006) believe that with respect to this terms, it's not enough just to gather information on a competitor, Analyzing and interpreting the information is as important as collecting it. (Wheelen T.L. and Hunger J.D.2006) defined environmental scanning as it is the monitoring, evaluating and disseminating of information from external and internal environments to key people within the corporation and both internal and external elements will determine the future of the corporation. The researchers defined Environmental Scanning as it requires an analysis of what is happening in external environment (which includes industry forces and general forces) and internal environment (which includes forces such as the corporate culture, structure and resources) and an evaluation of current resources (strength and weakness) and an assessment of (opportunities and threats) present in the environment as described in (figure 1.1). In any business environment SWOT analysis can help gauge the strengths, eliminate weaknesses, and exploit opportunities in a given market and avoid or deduce threats from competitors. The key benefits of a properly conducted environmental scanning are save time and efforts in generating leads, make profitable deals with more suitable distributors, reduce our time to market, not waste cash on ineffective campaigns.

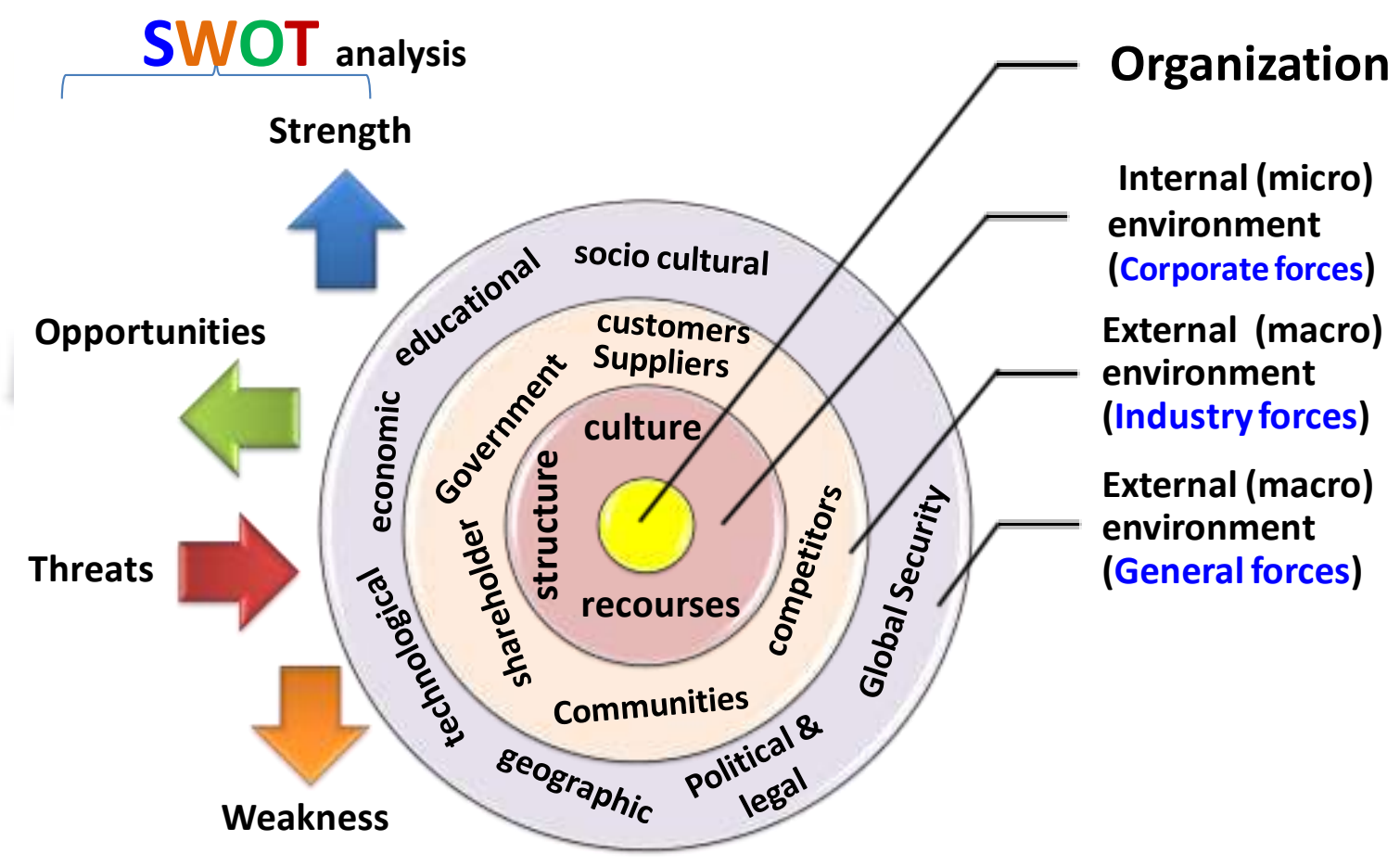

Figure 1.1, describe Organization environmental scanning forces, combined by Bahaa Alnady, Jan. 2014

There are several specific areas that should be considered, including the overall environment, the specific industry forces and general forces in external environment, and the corporate forces in internal environment of the firm. The resulting 
consequence of regular inspection of the overall environment is that an organization readily notes changes and is able to adapt its strategy accordingly. Refer to above (figure 1.1) External environment forces divided to (I) Industry forces such as (customers, suppliers, competitors, shareholder, government, and communities) and (II) General forces such as (socio cultural, educational, economic, technological, geographic, political and legal) additional to all these forces external environment consists of variables (opportunities and threats) that are outside organization and not within short-run control of top management. From other side, looking internally, there are several key areas that must be analyzed and addressed; this includes identifying the status of each existing line of business and unused resources. Internal environment forces divided to (1) Corporation culture (beliefs, expectations, and values), (2) Corporation structure (chain of command) and (3) Corporation resources (labors own "qualifications, experience, competencies, skills \& knowledge", Assets such as "capital, tools, equipments, goods \& properties") additional to all these forces internal environment consist of variables (strengths and Weaknesses) that are within the organization itself. People in an organization can use their competence to create value in mainly two directions: externally or internally, if managers of car or Soap Company direct the efforts of their people internally, they may create tangible structures such as machinery and tools and intangible structures such as better processes and new designs for products (Sveiby karl-erik, 2001).

\subsubsection{Internal Environmental Scanning}

Internal Environmental or micro-environmental scanning is first approach for any successful business man to start with it, since success come from inside human to outside, also success business come from inside organization to outside. Internal Environmental scanning is a means to determine the organization's structure and culture that may help or hinder the accomplishment of existing or new strategic goal and objectives (Baynes, 2005).

\subsubsection{Corporate Forces}

It included three main forces which are organization cultural, organization structural, and organization resources, these forces consider as a core of organizations.

Organization Cultural refers to express about attitudes, mores, beliefs, expectations, and values. It determines how employees behave in a particular organization and how they react to outsider or customers. According to (Needle, 2004) organizational culture represents the collective values, beliefs and principles of organizational members and is a product of such factors as history, product, market, technology, and strategy, type of employees, management style, and national cultures and so on. Corporate culture on the other hand refers to those cultures deliberately created by management to achieve specific strategic ends. (Ravasi and Schultz, 2006) state that organizational culture is a set of shared mental assumptions that guide interpretation and action in organizations by defining appropriate behavior for various situations.

Organization Structural refers to chain of command; it is hierarchical arrangement of lines of authority, communications, rights and duties of an organization. Organizational structure affects organizational action in two big ways. First, it provides the foundation on which standard operating procedures and routines rest. Second, it determines which individuals get to participate in which decision-making processes, and thus to what extent their views shape the organization's actions (Jacobides, M. G. 2007). In the 21st century, organizational theorists such as (Lim, Griffiths, and Sambrook, 2010) are once again proposing that organizational structure development is very much dependent on the expression of the strategies and behavior of the management and the workers as constrained by the power distribution between them, and influenced by their environment and the outcome.

Organization Resources refers to Assets (included capital, equipment, tools, and properties) and human resource (included qualifications, experiences, skills, competence, and knowledge). Resources is the suppliers' ability to provide the client company with expected service excellence and required number of resources, and to respond to changes and revisions on products and services are possible threats to the business industries. Generally, Organizations use different resources to accomplish goals, these major resources often described as (human resources, financial resources, physical resources and information resources) which Managers are responsible for acquiring and managing the resources to accomplish goals.

\subsubsection{External Environmental Scanning}

It called also macro-environmental, for any entrepreneur or business man the decision to start up new business in a given country is determined by scanning the external organization environment included Industry forces and General forces. Therefore, the authors chose to evaluate the bathtub sanitary ware Jeddah market as a part of environmental scanning and as a gate for sustainable competitive advantage. According to (Albright, 2004) environmental scanning makes it possible for a firm to deal with external environmental issues that may, otherwise, have been difficult to identify, it is not just about information gathering; rather, its purpose is to focus on future impacts and potential influences on the organization and how it can respond strategically. Environmental scanning enables a firm to highly focus on information from the external environment, as this will assist top management to become accessible to various sources that will assist them in their strategic planning and problem-solving situations (Popoola, 2001). Today organizations must understanding of external environment in order to respond in ways that will ensure the organization's survival and success. (Armstrong \& Kotler, 2011; Fifield \& Gilligan, 1997) described the macro-environmental factors as it's included competitive, political, economic, socio-cultural, technological, environmental and legal. Those factors not only influence a firm's activities in the short-term but also impact its long-term sustainability (Wheelen \& Hunger, 2002). 


\subsubsection{Industry Forces}

It included six main forces which are Shareholders, Government, Communities, Customers, Suppliers, and Competitors, each force play important role in organizations.

Shareholders; In order to realize the expectations of the shareholders in the form of the stability of the bathtub sanitary ware suppliers company's profitability, management require creativity and innovation in planning and running the business model. The company cannot grow by itself; the company must have the right business strategy. It is very disappointing for the company's shareholders that expect company to increase generating profits continuously and the company has a sustainable competitive advantage. Annual planning also to be revised since there are many new activities to be performed by company in current year. Such new activities to be prepared and have an agreement from shareholder are; new market segment, new production and service activities, New Organization, New financing scheme.

Government; - National and local government agencies have provided assistance to business industries, allowing them to explore opportunities for growth, payment of taxes, adherence to government policies, and improvement of the welfare of its citizenry.

Communities; Sanitary ware suppliers must Create business collaboration with sister company and communities. As an early stage, environmental scanning should conduct on communities too since sister company part from communities and all part of external environment if not Sanitary ware suppliers will have a lack of experience in sanitary ware bathtub business.

Customers; refer to end consumer, client, buyer, purchaser or retailers who usually purchased or recipient goods, services, products or idea obtained from a seller, vendor or supplier. There are two types of customers; external customer of an organization is a customer who is not directly connected to that organization (Tennant, Geoff, 2001). An internal customer who is directly connected to an organization such as stakeholder, employees or shareholders (Kendall, Stephanie D. 2007; Tennant, Geoff, 2001)

Suppliers; refer to any organization that provides human and material resources for business industries. Supplier is the extent to which such organization continuously offers its products and services in order for business industries to achieve their goals.

Competitors: A growing number of companies in Saudi Arabia at this time led to the business competition between companies that increasingly tight and competitive. This is a challenge for companies that can still survive and developed. Challenges also come from different companies with other factors, such as variations in consumer demand for quality products and services, technological developments, government policies, and the high price of raw materials which can cause high selling price, the expansion of many makers will increase the excess of production and will reduce the selling prices. That may threaten consumer demand for the products produced by same Industries (Firdaus A. and Hamsal M, 2013). From the Porter's five forces model we found that the market for bathtub sanitary ware segment to simple bathtub, message bathtub with Jacuzzi, message bathtub shower room. Bathtub is attractive products for hotels projects, villa`s, VIP customers, but for other segment such as standard apartments less attractive. The problem in bathtub is too many types available in Jeddah market, but not organize and mainly Chinese made available widely with low cost, many competitors focus to purchase Chinese bathtub due to less cost compare with European made especially for message bathtub with Jacuzzi, from other side simple bathtub we found that there re many types made in Saudi Arabia, Bahrain, and china available everywhere and there re high demand on it especially from all standard apartments. We can see the market attractiveness and business strength every segment of bathtub.

\subsubsection{General Forces}

Refer to the following force such as (socio cultural, educational, technological, economic, geographic, legal, political, and global security).

Socio Cultural; factor shave the greatest impact on the industries in terms of skills and competencies of workforce, attitude towards work, and changes in lifestyle. Socio cultural has to do with the totality of the prevailing values, norms, attitudes, mores, and beliefs in a society. These impact heavily on businesses, nay all the organizations that operate in such society.

Educational; one of high important factor that play big role in any environment, many business depend of type of people who work with and what the have qualification.

Technological; consider as very important force factor play big role to connect local market with Global market, Technology help a lot to control and manage internal and external business via network and B2B, B2C, and B2G. Internet is one of most important technology which has created e-commerce and a global digital economy with new opportunities. Social media such as websites Twitter, Facebook, Linkedln and Pinterest have already demonstrated their potential for getting information also mobile technology have a lot of potential for gathering information. There are premised on the belief that continual growth in a finite world is possible through the powers of technology, which will enable us to find new sources or provide alternatives.

Economic; the economic factors affecting the business industries these economic factors such as Inflation rate, variable interest rates, and economic growth were the top three factors perceived to affect business growth and operation as well as production, distribution, and consumption in an economy.

Geographic; this factor determine type of business which can be as well as determine life style. Geographic is the phenomena of the earth which effect usually business of organization in many ways, each organization adapted as per to 
geographic area, even many of them selected the require products or services as per to consumers living in same geographic area therefore business organization and people life style depends usually about the geographic area.

Legal and Political; factors refer to local and international politics and national changes in laws and policies. since existing government legal and policies are change from time to time and must be adhered to by organizations Understanding the legal and political climate will prepare business industries for suddenly changes that result from elections or changes in existing law, regulations, and policies. Changes in tax laws, availability of infrastructure and world oil, currency, and labor markets are legal and political factors that greatly affect business operations.

Global Security; Global security threats and issues are now an important issue affecting organizations, programs and projects worldwide. Every project, no matter how simple, small or local, must incorporate information security plans and procedures. Security issues include new viruses and virus protection software, internet security, international and local terrorism, identity theft, and physical security to protect against criminals (Pells David L. 2013)

\subsection{Communication Technology}

Technology are one of the main reasons that globalization has escalated in the past decade. Information technology and innovations have become smaller in size, more efficient and often more affordable. In communication technology, Mobiles have tended to become smart phones included many social media applications, as well as becoming more necessary tools for ever one in the world whether for personal use or for business. Technology has made the world seem a smaller place and assisted in the rise of globalization. Technology is developing databases which usually help to organize and analyze the information reported to organization from all sources such as websites, mobile phones networks via us statistic analysis systems (SPSS, Amos 7); technology is a great tool for any research analysts. According to Albright (2004), the emergence of new technologies can impact organizations' overall business and production processes. It is effective to monitor changes in technologies, mainly those that influence business efficiencies, changes in production, existing infrastructures, and rise of new products or services. The way business is carried out had witnessed a lot of transformations. New techniques come to replace the old ones, and give a new flavor to service delivery. In fact, competitions in most industries develop along the lines of technological advancement and innovation. Any business that is slow to adapt to technological changes is courting problems, not in the least, extinction. Communication technology such as smart phones, PC, smart LCD, video conferencing, social networks, search engines and virtual office technology has removed workplace boundaries that previously limited business expansion. With business technology, companies can target a wider customer base and grow to higher levels. Organizations face unprecedented challenges to their communication technology and environment. The speed change in communication technology and appear many network application such as Apple Apps, Android Apps (figure 1.2) affect business everywhere, combined with consumer awareness and interaction, means more than ever that business become changing in short time, many of organization run behind the latest communication technology. Apple continues to grow and increase market share, the unique productions of Apple lap-top, smart mobile phones, I-Pad, I-Pot made lot of changed in business environment as well as Samsung laptop, LCD, Smart mobile phones play big role in social and business strategies, today we can find many companies who hire specialist with social media or Android specialist or B2B manager who are necessary to growth business of any organization and supporting marketing Manager since marketing those days not only traditional but also virtual marketing and many communication technology application such as Tango, Viper, Skype, FreePP play lot of activity and make world small village. Consumers increasingly use Apps on multiple devices and operation systems, these behaviors prompting many organizations to use different approaches communication technology to reach and interact with consumer anytime and everywhere.
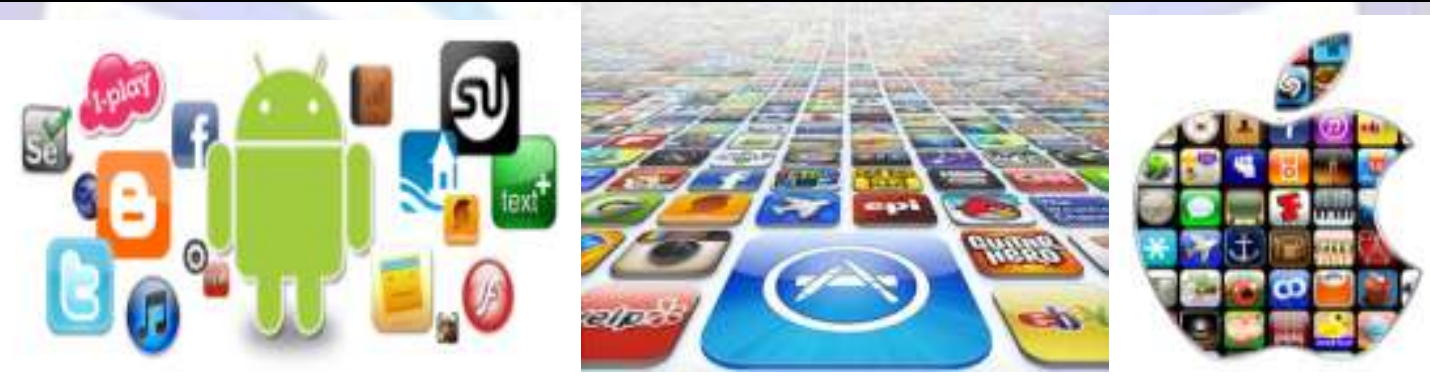

Figure (1.2) shows Apple Apps, Android Apps

Facebook, Twitter, YouTube, Pinterest are greatly influenced our use of the word friend and business. Nowadays communications create social and business media as tools to presenting ourselves, business and others. Social Networking Sites (SNS) consider as platforms for self-presentation more than blogs, web pages and smart-phones. The environment of Facebook, Twitter, YouTube, Pinterest (figure 1.3) and Linkedln allows others who access to our profile to see our products and friend who joined to same profile. Facebook and Twitter provides an alternative space for interaction that can more easily fit into a person`s busy schedule or interest area. Social media websites such as Facebook, Twitter, LinkedIn, Pinterest and many others social and business media websites represent a huge opportunity for businesses to grab the attention of customers while simultaneously building a brand image. There are plenty of tactics that businesses can employ to do this including the creation of brand profiles on social networks such as Facebook fan pages and creative advertising via branded podcasts and applications, also known as apps. Social media is continuing to have a huge 
influence on business, marketing and on how businesses engage with their target market. The use of social media to share and engage with others continues to grow at an astounding rate, so it would be wise for any business to develop and implement a sustainable social media strategy in order to successfully take advantage of this rapidly changing environment.

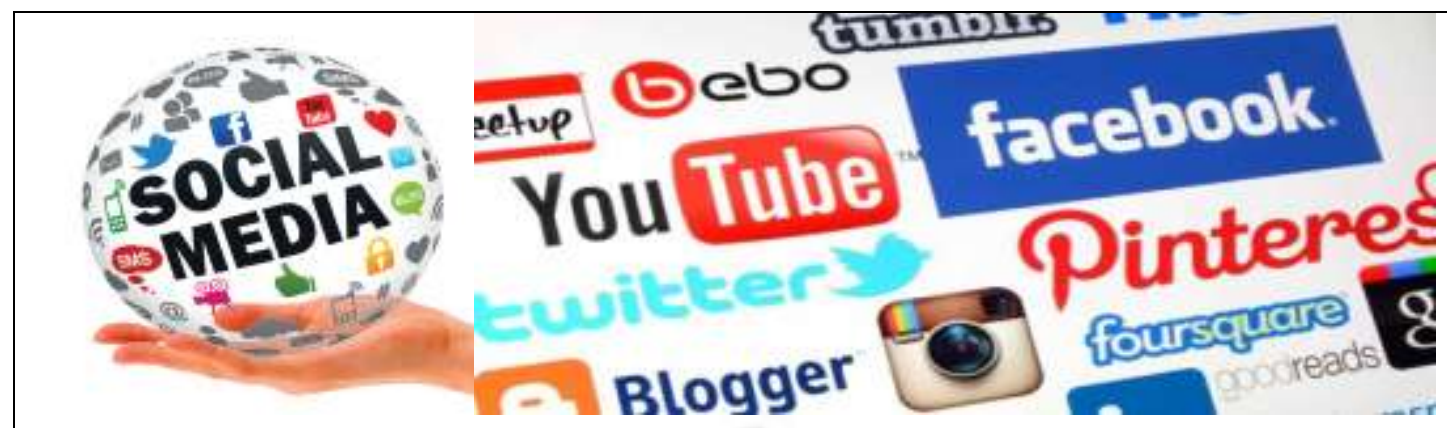

Figure 1.3 show social media which tools created via communication technology

Communication technology has changed our way of life, whether it is at home, at work, or at school. The internet and the development of digital technology (computer-based technology) in particular, have made the most significant impact in the field of information and communication technology in the past decade.

The internet has had an important role in connecting people in countries around the world to instantly contact each another through email, chat programs and video calls. This instant communication has revolutionized business and social lives. In Saudi market many supplier still does not know how to use communication technology in propel way, for example FGBM one of construction and trading company who supply market with sanitary ware product in Jeddah and Makkah who misused communication technology due to hiring unqualified employees with low salaries those employees ignore customer care and waste business time by sitting on office for hours on PC either for playing games or chatting via Facebook and yahoo messenger not for business, but for fun, we can find here that, the problem is not in the technology but in how it is used or abused, sometime technologies become environmentally harmful if we are not applied it in correct way. Communication technology design for purpose, unfortunately FGBM upper management not recognize the situation early for many reasons and that affect negatively all the whole operation of FGBM and drop business down recently, the researcher found that, many of FGBM employees time consumption on office because of using technology in negative way and sitting for hours on social media such as Facebook to do chatting not for business purpose but for entertainment, If upper management at least make training for those employees as group still they will failed, because the type of employees under quality, the only solution is to replace them with qualified team who know how they can use technology in positive way and connect all business partners and retailers of sanitary ware for example to show them new products of Bathtub or use social media to marketing bathtub products. The appropriate use of technology very important to success any business and sustainable competitive advantage, but if warehouse in-charge not recording new arrival goods regularly on database and delaying his work day by day, and finance manager not record sales regularly on database in propel way, wasting his time with secondary work, and delaying pay for salaries monthly, imagine internal environment how it will be, misused of technology and unorganized internal environment will impact negatively on any organization, this is life example for FGBM organization.

\subsection{Superior Competitive Advantage (SCA)}

The competitive advantages/disadvantages analyzed from the internal and external competitive environment, such as strength, weakness, opportunities and threats in SWOT analysis, provide important and specific messages to position industrial development trends and formulate the development strategies (Grant, R. M. 1991). Therefore, achieving a competitive advantage is a major pre-occupation of senior managers in the competitive and slow growth markets, which characterize many businesses today and the sources of competitive advantage have been a major concern for scholars and practitioners for the last two decades (Henderson, 1983; Porter, 1985; Barney, 1991; Grant, 1991; Peteraf, 1993). Thus, it is understood that across sectors most firms should recognize that attaining competitive advantages is the most challenging issue facing firms for centuries. This concern has lead to the development of resource-based and knowledgebased theories that examine the relationship between core resources and capabilities; sustainable competitive advantage and above normal performance. According to Porter (1985) the principal types of competitive advantage are low cost producer, differentiation, and focus. The firm has a competitive advantage if it is able to deliver its product or service at a lower cost than its competitors. If the quality of its product is satisfactory, this will translate into higher margins and higher returns. Generally any market driven by global competition and slow-growth economies and industries, many organizations search for new ways to achieve and retain a competitive advantage (Sunhilde, 2011). A competitive advantage could basically be defined as the advantage or ability a firm has over its rivals because the company wants the gap between perceived value and cost of the product to be greater than the competition Porter, M. (1980). Knowledge resource is unique and valuable for a link to competitive advantage, Knowledge is critical to the capabilities of effective organizational learning (Wu and Lin, 2009). Good segmentation of the market and hence a better knowledge of customers is key to increasing competitiveness (Banabakova and Stoyanov, 2009). Managers, on one side, understand that the only 
competitive advantage that the future firm will have lies in its ability to learn faster than its competitors (DeGeus, 1988; Hansen, 2002). Competitive advantage creation must be a choice of management and it must really fit to achieve results (Pressman and Steven, 1991). Many companies have built sustainable and superior competitive advantage through their choice of right human recourse people who have the ability to select right sales team and right distribution team. Over the years, business models have become much more sophisticated therefore selecting sales and distribution approach has become a key element of a successful business model (Sunhilde, 2011). In addition many business people consider customer service as central to organizational effectiveness, particularly in Sanitary ware outlet where employees' interactions with customers have a strong effect on customers satisfaction. (Turban et al, 2006) believes that any organization seeks a competitive advantage in their industries in other word an advantage over competitors in some measure such as cost, quality, or speed. One factor play big role in any market which is Product price. Product price elasticity is affected by substitute goods as more substitutes become available the demand becomes more elastic, since customer has more alternatives (Alnady Bahaa et.al, Nov.2013). Cost leadership is one of Porter's two types of competitive advantage; the cost leader delivers a product of acceptable quality at the lowest possible cost. It attempts to open up a significant and sustainable cost gap over all other competitors. The cost advantage is achieved through superior position in relation to the key cost drivers. Cost leadership translates into profits if the cost leader can command the average prices in the industry. On the other hand, cost leaders must maintain quality that is close to, or equal to, that of the competition.

Today, everything has changed due to globalization markets. E-commerce may help reach customers within an existing market who may not have visited vendor's outlet; e-commerce is an innovative application of information technology by retail and global industries (Sunhilde, 2011). The modern way of business also changed, nowadays to achieve the low costs, the low prices, and attractive products, needed to be competitive, companies are thinking of international market instead of national (local) market. Demand for strong and superior competitive advantage has become a concern of every manager who is aware of the realities of the market. It is no longer enough to assume that good products will sell themselves, and that success today will be repeated in future (Porter M.E., 1980). From other side better management of the logistics chain means that customer service will become more efficient while lowering costs (Banabakova and Stoyanov, 2009). According to (Turban et al, 2006), porter's model has been used to develop strategies for companies to increase their competitive edge and it also demonstrates how IT can enhance the competitiveness of corporations. (Desouza K.C, 2001) that, Competitive intelligence can be done with technologies such as optical character recognition, intelligent agents and especially the Internet. The Internet is a company's most important tool to support competitive intelligence (Teo, 2000; Bell and Harari, 2000 and Buchwitz, 2002). (Power and Sharda, 1997) proposed a framework in which the Internet capabilities are shown to provide information for strategic decisions. There are a lot of studies have examined consumers' switching habits using the traditional store and online channels. Demographics including age, household income, and faintly composition, had a significant effect on consumer perception of benefits for both online and store shopping (Dholakia et al., 2000). Bhatnagar Ankit, (2006) believes the advances in IT have affected the lives of most of the human beings in their day-to-day lives. later, the type of business models might depend on how technology is used. Using technology, businesses can reach a large number of customers with minimal costs, A multichannel retailer refers to the company who sells products through a traditional channel and the internet, Virtual channels can also extend the product scope and product depth of physical channels by enabling firms to offer new products that they do not have to physically stock locally (Sunhilde, 2011). IT links a company with its business partners effectively and efficiently (Clemons and Hann, 1999). IT enables companies to reduce costs (Schwartz, 2000). IT creates innovative applications that provide direct strategic advantage to organizations (Bhise et al., 2000). In Saudi Arabia we have many firms in sanitary ware industry, the fact of the matter is that, there is unorganized sector whereas rest is organized sector comprising of the sanitary ware industry in Makkah and Jeddah Cities are divided in two sectors. The organized sector majorly consisting of suppliers companies (M/s. SARA - Saudi Arabia Agencies Ltd, M/s. Traco Co, M/s. Al-Hayat Building Materials Co, M/s. Ebaa House Ceramic \& Marble Co, M/s. Saudi Marble \& Granite Factory Co, M/s. AISCO, M/s. Bani Thabyan Trading est...) who sale Sanitary ware (Bathroom Accessories, Mixers, and Bathtub) for the last 15-30 years and they have established their brand image. Generally unorganized sector's percentage of production capacity and also their sales in the local domestic Saudi Arabia market are higher than that of the organized sectors' sales. However, most literature has not clearly linked strategic management with sustainable competitive advantage. This paper, therefore, explores and discusses the role of environmental scanning and communication technology in helping business firms to achieve sustainable competitive advantage.

\section{Study Model}

Based on study hypothesis, the following study model was proposed in order to show the relationships among independent and dependent variables. As can be seen from the framework, the study investigates the impact of Environmental Scanning (ES) and Communication Technology (CT) on sustainable competitive advantage (SCA), where Environmental Scanning (ES) and Communication Technology (CT) are the independent variables positively related to Sustainable Competitive Advantage (SCA) as the dependent variable. This relationship was used to develop the hypotheses for this study. The model of the study is illustrated in below Figure (1.7) 


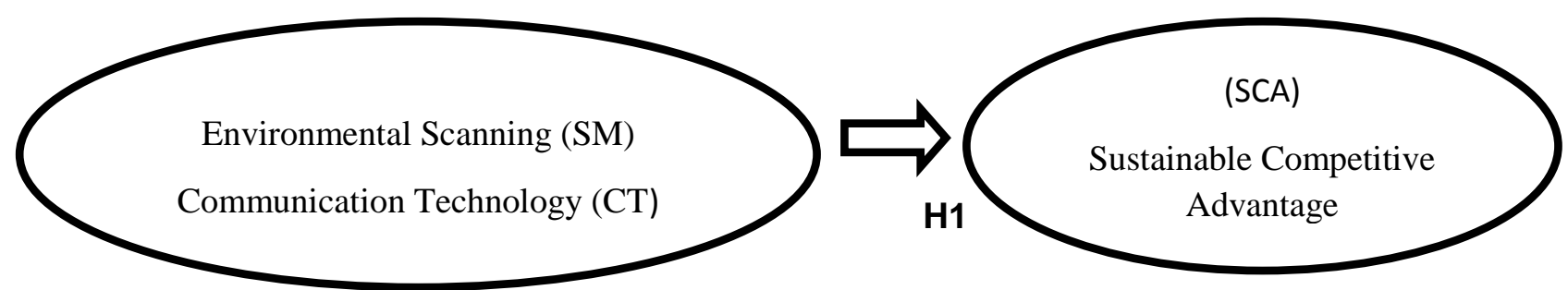

Figure (1.7) show Study Model

Therefore this model hypothesizes that Environmental Scanning and Communication Technology positively influence on Sustainable Competitive Advantage (H1).

\section{Methodology}

In the present study, a survey was carried out on a sample of 108 retailers who purchase sanitary ware (bathtub) from supplier's sanitary ware in Jeddah city, Saudi Arabia. Retailer's sanitary wares (bathtub) were selected randomly and a sample was chosen by convenience sampling as the total population was unknown, both the primary and secondary methods of data collection were used. A structured questionnaire was administered among the customers to collect the response as primary data. The secondary source of data collection was through journals, books, magazines and through informal discussion with Retailers sanitary ware. The instrument used for data collection is a questionnaire titled "environmental scanning and communication technology on sustainable competitive advantage" developed by the researcher. The 17-items questionnaire was based on a careful synthesis of environmental scanning and communication technology on sustainable competitive advantage, Age, Gender, Educational level, Experience and Functional level. The questionnaire was divided into four parts. Which are Parts one, two, three and four. Part one was designed to elicit personal information about respondents while part two, three and four focused and consisted of 17 items designed to elicit information on environmental scanning and communication technology on sustainable competitive advantage on a five point Likert scale of Strongly Agree (SA), Agree (A); Mix feeling (MF); Disagrees (D) Strongly Disagree (SD) with points awarded in descending order of $5,4,3,2$, and 1.

\subsection{Measures}

All of our measures were created or adapted from scales that have been validated in prior research. The scales were customized wherever needed to make them relevant to the context of our study. All constructs were measured using fivepoint Likert scales with anchors strongly disagree $(=1)$ and strongly agree $(=5)$. All items were positively worded. Independent variables; Environmental Scanning (ES) measures by use 4-items questionnaire were designed and adopted by researchers and Communication Technology (CT) measures by use 5 -items questionnaire were designed and adopted by researchers.

In regards of dependent variables; Sustainable Competitive Advantage (SCA) measures were adapted from previous studies, 6-items questionnaire were designed and adopted from (Wu and Lin, 2009; porter, 1985; Im and Workman 2004; Clemons and Hann, 1999; Schwartz, 2000 and Sunhilde, 2011). The researcher used questionnaire of this study, based on the review of the literature and study measures, hypothesis was formulated as follows: H1. Environmental Scanning (ES) and Communication Technology (CT) have a significantly positive effect on Sustainable Competitive Advantage (SCA) in Jeddah city, KSA.

\subsection{Sample Profile}

In order to minimize possible response bias, instructions emphasized that the study focused only on their personal opinions. There were no rights or wrong answers. After completion, the questionnaires were checked and collected by the researcher. However, due to some invalid questionnaires which were removed from the sample. The total sample size was 108, Table I shows the characteristics of the sample. 
Table I. Frequency

\begin{tabular}{|c|c|c|c|}
\hline General Information & Details & Frequency & \% Percent \\
\hline \multirow[t]{4}{*}{ Age group } & less than 30 & 48 & 444.4 \\
\hline & $30-$ less than 40 & 48 & 44.4 \\
\hline & 40 - less than 50 & 9 & 8.3 \\
\hline & 50 years and more & 3 & 2.8 \\
\hline \multirow[t]{2}{*}{ Gender } & Male & 108 & 100 \\
\hline & Female & 0 & 0 \\
\hline \multirow[t]{5}{*}{ Educational level } & High school graduates or below & 17 & 15.7 \\
\hline & Diploma & 34 & 31.5 \\
\hline & Bachelor & 52 & 48.1 \\
\hline & Master & 5 & 4.6 \\
\hline & $\mathrm{PhD}$ & 0 & 0 \\
\hline \multirow[t]{4}{*}{ Experience } & less than 5 years & 22 & 20.4 \\
\hline & 5- less than 10 & 47 & 43.5 \\
\hline & 10- less than 15 & 26 & 24.1 \\
\hline & 15 years and more & 13 & 12 \\
\hline \multirow[t]{3}{*}{ Functional level } & Low Management & 14 & 13 \\
\hline & Mid Management & 67 & 62 \\
\hline & High Management & 27 & 25 \\
\hline
\end{tabular}

In the preliminary analysis, age 48 (44.4 percent) belong to the less than 30 year-old category, 48 (44.4 percent) belonged to the 30 - less than 40 year old category, 9 (8.3 percent) belonged to the 40 - less than 50 year old category, 3 (2.8 percent) belonged to the 50 year old \& more category. , with regard to 108 (100 percent) male were 0 (0 percent) female. In addition, 17 (15.7 percent) of the participants were high school graduates or below, 34 (31.5 percent) of the participants were diploma holders, whereas 52 (48.1 percent) were Bachelor degree, and 5 (4.6 percent) were Master degrees holders, 0 (0.0 percent) were $\mathrm{PhD}$ degrees holders. With regard to Experience, 22 (20.4 percent) belong to the less than 5 years experience, 47 (43.5 percent) belonged to the 5 - less than 10 years experience, 26 (24.1 percent) belonged to the 10- less than 15 years experience, and 13 (12 percent) belonged to the 15 years and more years experience. Finally with regard to functional level 14 (13 percent) belonged to the Low Management, 67 (62 percent) belonged to the Mid Management, and 27 (25 percent) belonged to the High Management.

\subsection{Psychometric properties and dimensions of Environmental Scanning ,Communication Technology scale and Sustainable Competitive Advantage}

Kaiser-Meyer-Olkin and Bartlett's Test of Sphericity has been used as Pre-analysis testing for the suitability of the entire sample for factor analysis as recommended by Comrey (1978), the value of The Kaiser-Meyer-Olkin measure was used to assess the suitability of the sample for each unifactorial determination. The KMO values found (see Table V) are generally considered acceptable (Kim and Mueller, 1978). All factors in each unifactorial test accounted for more than 24 percent of the variance of the respective variable sets. This suggests that only a small amount of the total variance for each group of variables is associated with causes other than the factor itself, and the Bartlet tests of sphericity was significant at $p<0: 01$, thus, indicating that the sample was suitable for factor analytic procedures (see Table V). It show that, KMO and Bartlett's Test shows Kaiser-Meyer-Olkin Measure of Sampling Adequacy $=0.551$, Approx. Chi-Square $=11.523$, Df $=3$, the significant $0.009 \%<0.05 \%$ which mean all variables of study statistically significant. Component Matrix for dependent variable Sustainable Competitive Advantage $(\mathrm{SCA})=0.765 \mathrm{good}$, and for independent variables Environmental Scanning $(\mathrm{ES})=0.646$ good and Communication Technology $(\mathrm{CT})=0.611$ Good. 
Table II. Kaiser-Meyer-Olkin and the Bartlett's Test of Sphericity

\begin{tabular}{|c|c|c|c|c|}
\hline \multirow{2}{*}{ Variables } & \multirow{2}{*}{$\begin{array}{c}\text { Kaiser-Meyer- } \\
\text { Olkin Values }\end{array}$} & \multicolumn{2}{|c|}{ Bartlett's Test of Sphericity } \\
\cline { 3 - 5 } & & Approx. Chi-Square & df & Sig. \\
\hline ES & 0.544 & 13.050 & 0.38739 & 0.646 \\
\hline CT & 0.486 & 12.791 & 0.30643 & 0.611 \\
\hline SCA & 0.527 & 51.510 & 0.39967 & 0.765 \\
\hline
\end{tabular}

\subsection{Reliability and validity of the survey instrument}

The survey instrument with 15 items was developed based on two variables as independent variables: Environmental Scanning (ES1 - ES4), Communication Technology (CT1 - CT5), and one dependent variable, Sustainable Competitive Advantage (SCA1-SCA6). The instrument was evaluated for reliability and validity. All individual loadings were above the minimum of 0.5 recommended by Hair et al. (1998). In order to achieve the reliability and validity of questionnaires forms which were used in this research, the questionnaire has been translated into Arabic language in additional of English version. The questionnaire for both language versions were discussed and compared to ensure that they were conceptually equivalent. Appendix (1.1) of questionnaire was used for the main study.

Table III Factor analysis of independent variable Environmental Scanning (ES), Communication Technology (CT) and dependent variable Sustainable Competitive Advantage (SCA)

\begin{tabular}{|c|c|c|c|c|c|}
\hline & ( (Table III ) $\quad$ Variables & Loadings & Eigenvalue & Variance & Reliability \\
\hline ES & Environmental Scanning (independent) & & 1.376 & 45.852 & 0.646 \\
\hline ES1 & $\begin{array}{l}\text { The supplier gathering information about sanitary ware } \\
\text { customers in regular basis. }\end{array}$ & 0.763 & & & \\
\hline ES2 & $\begin{array}{l}\text { The supplier gathering information about sanitary ware } \\
\text { products and competitive brands in regular basis. }\end{array}$ & 0.686 & & & \\
\hline ES3 & $\begin{array}{l}\text { The supplier prepares for the future by identifying new } \\
\text { trends and opportunities in the marketplace for } \\
\text { creating new sanitary ware product. }\end{array}$ & 0.558 & & & \\
\hline ES4 & $\begin{array}{l}\text { Global economic crisis effect supplier business of } \\
\text { sanitary ware in short and long terms. }\end{array}$ & 0.435 & & & \\
\hline CT & Communication Technology (independent) & . & 0.903 & 30.086 & 0.611 \\
\hline CT1 & $\begin{array}{l}\text { Generally communication technology help supplier to } \\
\text { do business in efficient and effective way. }\end{array}$ & 4 & & & \\
\hline CT2 & $\begin{array}{l}\text { Website of supplier is essential in business and } \\
\text { guideline for all retailers to reach to information about } \\
\text { products in easy and quick way. }\end{array}$ & 0.840 & & & \\
\hline CT3 & $\begin{array}{l}\text { Social Media such as Facebook, Tweeter help supplier } \\
\text { of sanitary ware to communicate with retailers and end } \\
\text { consumer in better way. }\end{array}$ & 0.620 & & & \\
\hline CT4 & $\begin{array}{l}\text { Using mobile application technology such as What-up, } \\
\text { Tango, SMS, and emails, help supplier of sanitary } \\
\text { ware to do quick decisions and serve market well. }\end{array}$ & 0.579 & & & \\
\hline CT5 & $\begin{array}{l}\text { Enterprise resource planning (ERP) help supplier to } \\
\text { organize retailers account and process sanitary ware } \\
\text { orders in short time }\end{array}$ & 0.736 & & & \\
\hline & Variables & Loadings & Eigenvalue & Variance & Reliability \\
\hline SCA & Sustainable Competitive Advantage (dependent) & & 0.722 & 24.062 & 0.765 \\
\hline SCA1 & $\begin{array}{l}\text { The supplier of sanitary ware is more likely to learn } \\
\text { from the experience of others competitors while his } \\
\text { resource is more limited and his performance is not }\end{array}$ & 0.675 & & & \\
\hline
\end{tabular}




\begin{tabular}{|l|l|l|l|l|l||}
\hline \hline & satisfactory. & & & & \\
\hline SCA2 & $\begin{array}{l}\text { The supplier of sanitary ware delivers a product of } \\
\text { acceptable quality at the lowest possible cost that is } \\
\text { close to, or equal to, that of the competition. }\end{array}$ & 0.661 & & & \\
\hline SCA3 & $\begin{array}{l}\text { The supplier of sanitary ware strategy for competitive } \\
\text { advantage is based on his understanding of } \\
\text { customers' needs and how he can create greater value } \\
\text { for customers. }\end{array}$ & 0.541 & & & \\
\hline SCA4 & $\begin{array}{l}\text { IT links supplier of sanitary ware with its business } \\
\text { partners effectively and efficiently and reduce his } \\
\text { costs. }\end{array}$ & 0.755 & & & \\
\hline SCA5 & $\begin{array}{l}\text { The supplier provides sanitary ware products to the } \\
\text { marketplace in an innovative, continually changing, } \\
\text { and broad manner. }\end{array}$ & 0.598 & & & \\
\hline SCA6 & $\begin{array}{l}\text { E-commerce may help reach customers within an } \\
\text { existing market who may not have visited sanitary } \\
\text { ware vendor's outlet. }\end{array}$ & 0.774 & & & \\
\hline
\end{tabular}

Factor analysis and reliability analysis were used in order to determine the data reliability for the independent variable (ES), (CT), and dependent variable (SCA) measures. A within factor, factor analysis was performed to assess convergent validity. The results of the factor analysis and reliability tests are presented in Table III. On the basis of Cattel (1966) and Hair et al. (1998) criterion, factors with eigenvalues greater than 1.0 and factor loadings that are equal to or greater than 0.50 were retained. 15 items, loading under three factors, were extracted from the analysis. The three factors captured all of the variance with $24.062 \%$, and $45.852 \%$ of the variance respectively.

\subsection{Correlation analysis: relationships between the variables}

The correlation matrix in (Table V) further indicates that Environmental Scanning (ES) and Communication Technology (CT) were positively and moderately correlated with Sustainable Competitive Advantage (SCA). The correlation coefficients between the independent variables environmental scanning and communication technology and the dependent variable sustainable competitive advantage were less than 0.9 , indicating that the data was not affected by a collinearity problem (Hair et al., 1998). These correlations are also further evidence of validity and reliability of measurement scales used in this research (Barclay et al., 1995; Hair et al., 1998). As can be seen in Table V, the correlation coefficients for the variables ES and CT under investigation were relatively ranging as 0.098 , and the variables ES and SCA were relatively ranging as 0.239. Further the variables CT and SCA were relatively ranging as 0.217 . Environmental Scanning was highly correlated with Sustainable Competitive Advantage $(r=0.239, p \leq 0.01)$. And Communication Technology was highly correlated with Sustainable Competitive Advantage $(r=0.217, p \leq 0.01)$. Environmental Scanning (ES) and Communication Technology (CT) had significant positive correlations ( $p, 0.01)$ with Sustainable Competitive Advantage (SCA).

Table IV. Summary of Means, standard deviations, and correlations of Environmental Scanning (ES), Communication Technology (CT) and dependent variable Sustainable Competitive Advantage (SCA)

\begin{tabular}{|c|c|c|c|c|c|}
\hline Variables & Mean & S.D & ES & CT & SCA \\
\hline Environmental Scanning (ES) & 3.2569 & 0.38739 & $\mathbf{1 . 0 0 0}$ & 0.098 & 0.239 \\
\hline Communication Technology (CT) & 3.8741 & 0.30643 & & $\mathbf{1 . 0 0 0}$ & 0.217 \\
\hline ble Competitive Advantage (SCA) & 3.9475 & 0.39967 & & & $\mathbf{1 . 0 0 0}$ \\
\hline
\end{tabular}

Notes: Correlation is significant at the ${ }^{*} 0.01$ levels (two-tailed)

\section{Descriptive statistics analysis}

As show in Above (table IV) the mean=3.2569, $\mathrm{SD}=0.38739$ for Environmental Scanning (ES) and the mean $=3.8741$, $\mathrm{SD}=0.30643$ for Communication Technology $(\mathrm{CT})$ finally the mean $=3.9475, \mathrm{SD}=0.39967$ for Sustainable Competitive Advantage (SCA).

It is clear that the highest standard deviation was for question (SCA1) Sustainable Competitive Advantage $=1.06325$ with Mean 3.4815 this indicate that the answers were less homogeneous, and the lowest standard deviation for question (CT4) Communication Technology $=0.66796$ with mean 4.2407 


\section{Multiple regression analysis}

HYPOTHESIS H1: There is positive direct effect of Environmental Scanning (ES) and Communication Technology (CT) on Sustainable Competitive Advantage (SCA) in Jeddah city at level $(\alpha \leq 0.05)$. To test this hypothesis, Multiple Regression Analysis (coefficient beta) was used between (ES) and (CT) as independent variable, and (SCA) as dependent variable. The entire model has a significant effect on (SCA) $(0.000<0.05)$.

UUHypothesis One (H1): There is positive direct effect of Environmental Scanning (ES) and Communication Technology (CT) on Sustainable Competitive Advantage (SCA) in Jeddah city at level $(\alpha \leq 0.05)$.

Multiple regression analysis was employed to examine the impact of Environmental Scanning (ES) and Communication Technology (CT) on Sustainable Competitive Advantage (SCA). It is a constructive statistical technique that can be used to analyze the association between a single dependent and several independent variables (Hair et al., 1998). Based on this method, the main independent variables (ES, CT) and dependent variable (SCA) were entered together. The detail of the regression output was shown in below Table (VI).

Table V. Regression Summary of the impact of Environmental Scanning (ES), Communication Technology (CT) on Sustainable Competitive Advantage (SCA)

\begin{tabular}{|c|c|c|c|c|c|c|}
\hline & \multirow[t]{2}{*}{.Model } & \multicolumn{2}{|c|}{$\begin{array}{c}\text { Unstandardized } \\
\text { Coefficients }\end{array}$} & $\begin{array}{l}\text { Standardized } \\
\text { coefficients }\end{array}$ & \multirow[t]{2}{*}{$\mathbf{T}$} & \multirow[t]{2}{*}{ Sig. } \\
\hline & & B & Std. error & B & & \\
\hline \multirow[t]{3}{*}{1} & (Constant) & 5.675 & 0.541 & & 10.488 & 0.000 \\
\hline & Environmental Scanning (ES) & 0.227 & 0.096 & 0.220 & 2.357 & 0.020 \\
\hline & Communication Technology (CT) & 0.255 & 0.122 & 0.196 & 2.098 & 0.038 \\
\hline
\end{tabular}

According to above (Table VI), the Standardized coefficient (beta) value as following:-

Sub-Hypothesis (H1a): There is positive direct effect of Environmental Scanning (ES) on Superior Competitive Advantage (SCA) in Jeddah cities at level $(\alpha \leq 0.05)$.

The result of ES is statically significant $(0.020<0.05)$, this agrees with sub- hypotheses $(\mathrm{H} 1 \mathrm{a})$ : there is effect between the Environmental Scanning (ES) and Sustainable Competitive Advantage (SCA), since $t=2.357$ with sig. $=2 \%<5 \%$, therefore there is significant direct effect of (ES) on (SCA).

Sub-Hypothesis $(\mathrm{H} 1 \mathrm{~b})$ : There is positive direct effect of Communication Technology (CT) on Superior Competitive Advantage (SCA) in Jeddah cities at level $(\alpha \leq 0.05)$.

The result of CT is statically significant $(0.038<0.05)$, this agrees with sub- hypotheses $(\mathrm{H} 1 \mathrm{a})$ : there is effect between the Communication Technology (CT) and Superior Competitive Advantage (SCA), since $t=2.098$ with sig. $=3.8 \%<5 \%$, therefore there is significant direct effect of (CT) on (SCA).

Main HYPOTHESIS (H1): There is positive direct effect of Environmental Scanning (ES) and Communication Technology (CT) on Sustainable Competitive Advantage (SCA) in Jeddah city at level $(\alpha \leq 0.05)$.

The result of $(E S$ and $C T)$ are statically significant $(0.005<0.05)$, this agrees with the main hypothesis $(\mathrm{H} 1)$ : there is effect between the Environmental Scanning (ES) and Communication Technology (CT) and Sustainable Competitive Advantage $(S C A)$, since $t=10.488$, and $F=5.517$ with sig. $=0.5 \%<5 \%$, therefore there is significant direct effect of (ES and CT) on (SCA). Above (table $\mathrm{VI}$ ) also shows that Environmental Scanning $(B=0.220)$ had a significant and positive effect on (SCA). Communication Technology (B

$=0.196)$ had a significant effect and positive effect on (SCA) which all independents variables had a significant effect and positive effect on (SCA). This provides evidence to support main hypothesis $\mathrm{H} 1$.

\section{Conclusion}

The researcher believes that the current study has contributed to some extent in the developing understanding of Environmental Scanning and Communication Technology as the gate for Sustainable Competitive Advantage of Sanitary Ware (Bathtub) Suppliers in Jeddah city, Kingdom of Saudi Arabia. The real success of any organization or business lies in Environmental Scanning (ES) and Communication Technology (CT) as approach to Sustainable Competitive advantage (SCA). This article is valuable in light of the general guidance of the relationship between Environmental Scanning, Communication Technology and Sustainable Competitive advantage. In addition, this 
article contributes to redressing this imbalance by focusing on (ES, CT) in detail. It provides insights into underresearched question of Does the Environmental Scanning and Communication Technology a gate for Sustainable Competitive advantage of Sanitary Ware (Bathtub) Suppliers in Jeddah city?

The most important finding is that suppliers are faced with a lot of challenges, majorly uncertainties, in the business environment that need to be dealt with. If supplier does not apply environmental scanning and use technology, the application of business and competitive advantage is almost of no significant impact. In case, a company does not take the time to think and implement environmental scanning and right technology may turn out completely useless, increasing risk of error, costly mistakes, and misunderstanding market needed. From another side, the researcher finding is that, Suppliers can be achieving or bettering agreed organization goals through the development and implementation of Environmental Scanning and Communication Technology. That strategy will reflect the organization's values, recognize its strengths and weaknesses compared to the competition, and have a view on the direction of the market in which it operates. The role of environmental scanning and communication technology are importance to identify and maximize of opportunities, minimize of threats, particularly in the area of planning and designing strategies of organization. It helps to do forecast the future factors that play in the business environment. Communication technology saves times by speeding up the work flow process. Digital filing systems save space, paper and printing costs, the use of computer systems allow corrections to be made instantly. The researcher finds that, one factor play big role in Saudi Arabia Market which is Product price. Sanitary ware product price elasticity is affected by substitute goods as more substitutes become available the demand becomes more elastic, since customer has more alternatives. Sanitary ware (Bathtub) products are perceived more costly in respect to its competitors. Therefore customer can divert to some less costly brand. The researcher found that, simple bathtub usually available in the market either made in Saudi Arabia or Bahrain, very a few brands international such as ROCA available in Jeddah market due to high competition in prices usually local made cheaper than international made. In regards of bathtub with Jacuzzi researcher found that, there are many Chinese brands such as (Wisemaker, SSWW, Potter, Sannora, Ocean...etc) available widely in Jeddah market sanitary ware outlet with different sizes, specifications, style and price which give very good variety to customers to select what he need. In the same time very rarely to find bathtub with Jacuzzi made in Europe due to high price in Jeddah market usually customer look for lowest prices with guarantee on product. Some of local sanitary ware supplier creates his own brand name for bathtub Jacuzzi such as brand (Silver) which is own brand for M/s. Ebaa House Ceramic \& Marble Co. (Appendix 1.2) description for sanitary ware (Bathtub) mostly are international brands available in Jeddah city, Saudi Arabia. Based on the SWOT analysis, the conditions for sanitary ware (bathtub) industry in Jeddah city are:

A) Strength can be such as (understand market positioning and market segmentation, own strong company image and strong bathtub brand name, dealing with varieties of Bathtub items and price, ability to supply big project in short period, and using communication technology in all aspects between all parties).

B) Weakness such as (demographics differentiate and low qualifications between employees of sanitary ware suppliers, retailers and consumers, also limited resource of sanitary ware supplier, poor experience in bathtub field, poor supply chain management, ignore market study, and poor communication technology).

C) Opportunities such as (high rise building open high demand on sanitary ware -bathtub, New investment in constructions sector increase success of sanitary ware business, strong economy in Saudi Arabia support and increase stability of sanitary ware business, big geographic area of Jeddah city enable sanitary ware supplier to extend business and cut biggest market share, availability of communication technology help to reach to maximum number of customers).

D) Threat such as (enter new competitors with less price and good quality, local made of sanitary ware effect business of international sanitary ware since the first usually sale with less price and can be delivery in short period, enter new technology of sanitary ware included useful options, Increasing the capacity and facilities of major competitors).

With the environmental scanning variable and communication technology variable the researchers found that each of those independent variables which they have strong effect as sustainable competitive advantage. At the end of the day, company's profit will remain fluctuated according to the market price of raw material, when the world market higher than local, local bathtub will generate profit. In contrary, when local market price is lower, importing bathtub will generate loss since bathtub local made will be cheaper and less cost from imported one. The fluctuated profit earned, mostly defined by inflexibility acquisition of raw material which is the major cost of product. By this identification above, we conclude the issues that most affect the company's income is primarily:

* Bathtub sanitary ware suppliers should reformulate its strategy by conduct environmental scanning regularly and using technology inside organization in order to be gate for sustainable Competitive Advantage.

* Even the market share were increased, the profit remain unstable due to increase in competition with similar bathtub products.

* Sales orders are fluctuating due to supply and demand and bathtub segment is a mainstay to earn huge profits that are not always earned.

* Value proposition that exist today are very similar to the competitors of bathtub.

* Bathtub supplier must developing and improving long term planning of the company. 
The study model is developed to imply various factors that are required to present more comprehensive set of factors that determine the overall sentiment of sustainable competitive advantage (SCA). The results of the main study have revealed that Suppliers of Sanitary ware did realise the benefits of Environmental Scanning (ES) and Communication Technology (CT) connected their willingness toward Sustainable Competitive Advantage (SCA) and use with some issues that have to be addressed previously in order to facilitate Sustainable Competitive Advantage (SCA) in Jeddah city. Not to mention with environmental scanning and Communication Technology a faster pace of getting results, a higher business to success and reduced failure rate.

\section{Recommendations}

This study is preliminary step to encourage researchers to undertake future studies, which shows the importance of Environmental Scanning and Communication Technology as a gate for Sustainable Competitive Advantage of sanitary ware (Bathtub) Suppliers in Jeddah city, Kingdom of Saudi Arabia. The researcher encourages all supplier of sanitary ware to apply environmental scanning and communication technology to success sanitary ware business, reduce risk, avoid mistake, and improve business as overall. In addition, environmental scanning and communication technology has a very important role to improve business relationship and satisfy both parties' suppliers and retailers. Environmental scanning is a complex set of business activity which requires care, skill, and expertise. In order to success any business organization, senior managers must do environmental scanning, internal analysis and SWOT analysis to look at the organization current business environment, senior managers must identify the factors that became the organization weakness as well as strengthens, evaluate and analysis problem. Organizations must maintain its competitiveness in order to win the competition and achieve or obtain maximum profit the organizations must work hard to maintain market share and consumer loyalty to their products in order to keep corporate profits and avoid losses. Eventually, we might get better at influencing the future, reducing more risks and helping ensure more successful completion of communication technology and environmental scanning. In the meantime, we need to keep our ears and eyes open, identify significant events and trends that might impact our business, projects, and develop more systematic methods for gathering information and using useful communication technology.

\section{Limitations}

The study is only concerned towards 108 retailers who purchased from suppliers sanitary ware in Jeddah City. It is assumed that respondents were honest in answering the questions while the survey was conducted. Moreover the study does not reflect the true picture of overall retailers from all the sanitary ware retailers either in Jeddah city or whole kingdom of Saudi Arabia.

\section{REFERENCES}

(1) Alnady Baha'a (May.2012); Effect of Customer Market Perceptions (CMP) and E- Loyalty on Business to Business Electronic Commerce (B2B EC) Success: An Empirical Study on Sample of E-retailers in Amman City. Thesis of Master degree in E-Business, Middle East University, Amman, Jordan.

(2) Alnady Baha`a, Al-Hawary and Alolayyan (Nov.2013); Strategic Management (SM) as a key for Superior Competitive advantage (SCA) of Sanitary Ware Suppliers in Kingdom of Saudi Arabia. International Journal of Management \& Information Technology. Vol. 7, No. 2, ISSN 2278-5612.

(3) Albright, K. S. (2004). Environmental Scanning: Radar for Success. The Information Management Journal, 38(3), 38-45.

(4) Abels, E. (2002). Environmental Scanning. American Society for Information Science and Technology, Vol. 28 No.3.

(5) Armstrong, G., \& Kotler, P. (2011). Marketing: An introduction. Boston.

(6) Badrinath, R. and Wignaraja, G. (2004). "Building Business Competitiveness", UN University Institute for New technologies, International Trade forms Issue 2.

(7) Banabakova, V. K., \& Stoyanov, M. S. (2009). Economic aspects of the relationship between logistics chain management \& competitive strategy. Buletin Stiintific, 14(2).

(8) Barclay, D. W., Thompson, R. \& Higgins, C. (1995), "The partial least squares (PLS) approach to causal modeling: personal computer adoption and use an illustration”, Technology Studies, Vol. 2 No. 2, pp. 285309.

(9) Barney, J. B. (1991). Firm resources and Sustained competitive advantage. Journal of Management, 17: 1, 99120.

(10) Baynes, R. G. (2005). An Internal Environmental Scanning Program for Richland Fire and Emergency Services. Retrieved from http://www.usfa.fema.gov/pdf/efop/efo38595.pdf.

(11) Bell, C. R., and O. Harari, (2000). Deep! Deep! Competing in the Age of the Road Runner. New York: Warner Books, 2000. 
(12) Bhise, H., et al. (2000). The Duel for Doorstep. McKinsey Quarterly, Vol. 27, No. 2, pp.19-25.

(13) Bhatnagar Ankit, (2006). Strategic Information Systems Planning: Alignment of 'IS/IT' Planning and Business Planning, Unitec New Zealand.

(14) Buchwitz, L. (2002). Using the Internet for Competitive Intelligence, [Online] Available: members.attcanada.ca/ lillyb/Cl/page1.html, 2002.

(15) Cattel, R.B. (1966) 'The scree test for the number of factors', Multivariate Behavioral Research, Vol. 1 No. 2 , pp.245-76.

(16) Choo, C. W. (2001). Environmental Scanning as Information Seeking and Organizational Learning. Information Research, 7(1). http://dx.doi.org /10.1.1.203.1594.

(17) Clemons, E. K., and I. H. Hann, (1999). Rosenblatt International: Strategic Transformation. Journal of MIS, Vol.25, No. 1, Fall, pp. 10-30.

(18) Comrey AL.(1978). Common methodological problem in factor analytic studies. Journal of Consulting and Clinical psychology, 46, 648-659.

(19) Coyne, K. P. (1986). Sustainable Competitive Advantage: What it is and what it isn't. Business Horizons, January: 54-61.

(20) Daake, D., Dawley, D. D. \& Anthony, W. P. (2004). Formal data use in strategic planning: An organizational field experiment. Journal of Management Issues, Vol. 51 No. 2, pp. 232-247.

(21) Debi S. Saini, 2006. Book Reviews: Blue Ocean Strategy: How to Create Uncontested Market Space and Make Competition Irrelevant, VIKALPA, 31(3), July - Sep.

(22) DeGeus, A. (1988). Planning as learning. Harvard Business Review, 66(2), 70-74.

(23) Desouza, K. C. (2001). Intelligent Agents for Competitive Intelligence: Survey of Application. Competitive Intelligence Review, Vol. 12, 4th quarter 2001, pp. 57-63.

(24) Dholakia,. R. R., \& Uusitalo, O. (2000). Switching to electronic stores: Consumer characteristics and the perception of shopping benefits. Under Review at International Journal of Retail and Distribution Management.

(25) Elenkov, D. S. (1997). Strategic Uncertainty and Environmental Scanning: The Case for Institutional Influences on Scanning Behaviour. Strategic Management Journal, 18(4), $287-302$. http://dx.doi.org/10.1002/(SICl)1097-0266

(26) Fifield, P., \& Gilligan, C. (1997). Strategic marketing management-planning and control, analysis and decision. Oxford: Butterworth-Heinemann.

(27) Firdaus Anton and Hamsal Mohammad (2013); The development of PT KHI's Business Model to enhance sustainable competitive advantage. School of Business and Management Institute Teknologi Bandung, Indonesia. The Indonesian Journal of Business Administration, Vol.2, No.15,2013:1818-1826.

(28) Grant, R. M. (1991). Contemporary Strategy Analysis: Concepts, Techniques and Applications. Cambridge: Black-well Publishers.

(29) Hansen, M.T., (2002). Knowledge networks: explaining effective knowledge sharing in multiunit companies. Organization Science, 13(3), 232-248.

(30) Hair, J.F. Jr, Anderson, R.E., Tatham, R.L. and Black, W.C. (1998) Multivariate Data Analysis, 5th ed., Prentice-Hall International, Upper Saddle River, NJ.

(31) Henderson, B. (1983). The Anatomy of Competition. Journal of Marketing, 47: 7-11.

(32) Im, S., and Workman Jr., J. P. 2004. "Market Orientation, Creativity, and New Product Performance in HighTechnology Firms" Journal of Marketing (68:2), pp. 114-132.

(33) Jacobides., M. G. (2007). The inherent limits of organizational structure and the unfulfilled role of hierarchy: Lessons from a near-war. Organization Science, 18, 3, 455-477.

(34) Kendall, Stephanie D. (2007). "Customer Service from the Customer's Perspective". In Fogli, Lawrence. Customer Service Delivery: Research and Best Practices. J-B SIOP Professional Practice Series 20. John Wiley and Sons. ISBN 978-0-7879-8310-9.

(35) Kim, Jae-On and Mueller, Charles W. (1978) Factor Analysis: Statistical Methods and Practical Issues , Sage, Beverly Hills, CA.

(36) Kroon, J. (1995), "General Management" (2nd Edition), Pearson South Africa, p. 76.

(37) Lim, M., G. Griffiths, and S. Sambrook. (2010). Organizational structure for the twenty-first century. Presented at the annual meeting of The Institute for Operations Research and The Management Sciences, Austin. 
(38) Needle, David (2004). Business in Context: An Introduction to Business and Its Environment. ISBN $\underline{978-}$ 1861529923.

(39) Onodugo, Vincent A., EWURUM, Uzoma J. F, 2013; Environmental Scanning: An Imperative for Business Survival and Growth in Nigeria. Journal of Economics and Sustainable Development. ISSN 2222-1700 (Paper) ISSN 2222-2855 (Online) Vol.4, No.7, 2013.

(40) Owualah, S.I. (1999) Entrepreneurship in Small Business Firms. Lagos: G-MAG Investment Ltd.

(41) Pells David L. (July.2013). Global Business Intelligence for Managers of Programs, Projects and Projectoriented Organizations. PM World Journal, Global Business Intelligence for Managers of Programs, Vol. II, Issue VII. Projects and Project-Oriented Organizations. Website: www.pmworldjournal.net - 2nd Edition.

(42) Peteraf, M. (1993). The cornerstones of competitive advantage: A resource-based view. Strategic Management Journal, 14: 179-191.

(43) Porter, M. (1980). Competitive Strategy: Techniques for Analyzing Industries and Competitors. Free Press, New York.

(44) Porter, M. E., and V. E. Millar (1985). How information gives you competitive advantage. Harvard Business Review, Vol. 63, No. 4, pp.149-158.

(45) Popoola, S. O. (2001). Scanning the Environment for Competitive Advantage: A Study of Corporate Banking Managers in Nigeria. Libri, 50, 210-216. http://dx.doi.org /10.1515/LIBR.2000.210

(46) Power, B. S. and Sharda, R. (1997). "Obtaining Business Intelligence on the Internet”, Long Range Planning, Vol. 42 No. 4, pp. 142-170.

(47) Pressman, Steven (1991), 'The Competitive Advantage of Nations, by M. E. Porter, Journal of Management, 17.

(48) Ravasi, D., Schultz, M. (2006), "Responding to organizational identity threats: exploring the role of organizational culture", Academy of Management Journal, Vol.49, No.3, pp. 433-458.

(49) Rehman, S. U. \& Ibrahim, M. S. (2013);A Study on Customer Satisfaction of Mobile Food Retailing in Salem City. CPS Journals, International Journal of Social Science Research, ISSN: 2289-3318, Vol. 1, Issue 1, pp: 49-58 (2013).

(50) Schwartz, E. (2000).Web Bots Enhance Self-Serve Experience. InfoWorld, February p. 7.

(51) Subramanian, R., Kumar, K. and Yauger, C. (1994) "The Scanning of Task environments in Hospitals: An Empirical Study" Journal of Applied Business Research 10 (4).

(52) Sunhilde Cuc (May.2011). Achieving Competitive Advantage through Using an Integrated Multi-selling Model. The Case from Romanian Linjerie Producer: Jolidon. University of Oradea, Romania. Journal of Electrical and Electronics Engineering, Volume 4, Number 1.

(53) Sveiby Karl-Erik, 2001; A knowledge-based theory of the firm to guide in strategy formulation. Swedish school of economics and business administration, Helsinki, Finland. Journal of Intellectual Capital; 2001; 2, 4; ABI/INFORM Global pg.344.

(54) Teo, T. S. H. (2000). Using the Internet for Competitive Intelligence in Singapore. Competitive Intelligence Review, Vol. 8 Issue 2, pp.16-23.

(55) Tennant, Geoff (2001). Six Sigma: SPC and TQM in manufacturing and services. Gower Publishing. ISBN 978-0-566-08374-7

(56) Turban, E., Leidner, D., Mclean, E. and Wetherbe, J. 2006. 'Information Technology for Management: transforming organizations in the digital age'. 5th ed, John Willy \& Sons.

(57) Turban (2008): Electronic Commerce A managerial Perspective Book. Pearson international Edition, New Jersey.

(58) West, J.J. (1988) "Strategy, Environment Scanning and their effect upon firm performance: an exploratory study of the food service industry." PhD Thesis presented for Virginia Polytechnic Institute and State University.

(59) Wheelen, T. L., \& Hunger, J. D. (2002). Strategic management and business policy. Upper Saddle River, NJ.

(60) Wheelen Thomas L., Hunger J. David (2006) Strategic Management and Business Policy $10^{\text {th }}$ Ed., Pearson Education, Inc.

(61) Wu Ing-Long and Lin Han-Chang (April.2009); A Strategy-Based Process for Implementing Knowledge Management: An Integrative View and Empirical Study. Journal of the American society for information science and technology, 60(4):789-802, 2009. 


\section{Appendix}

Appendix 1.1: Description for Sanitary ware Categories which available in Makkah and Jeddah cities, Saudi Arabia

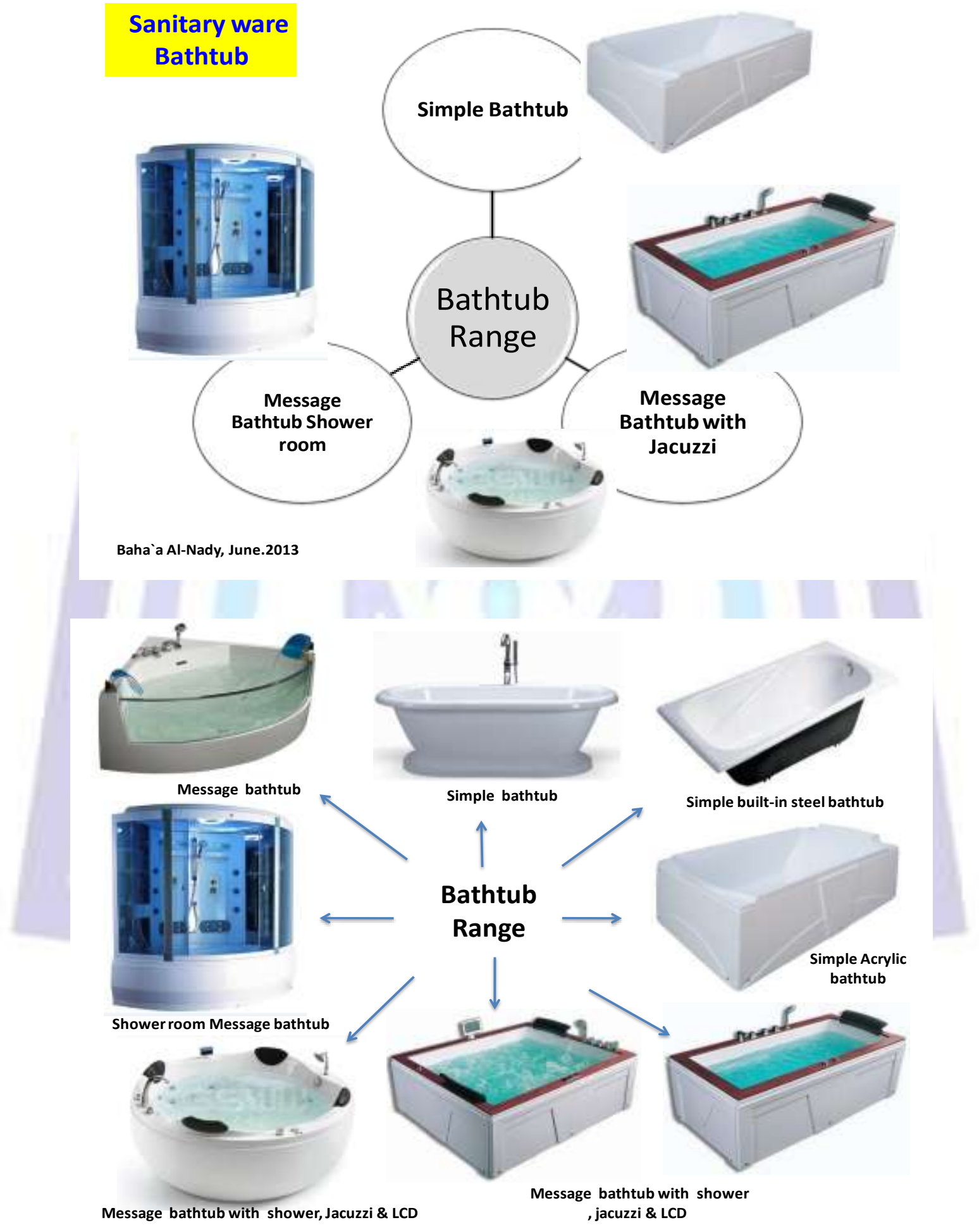




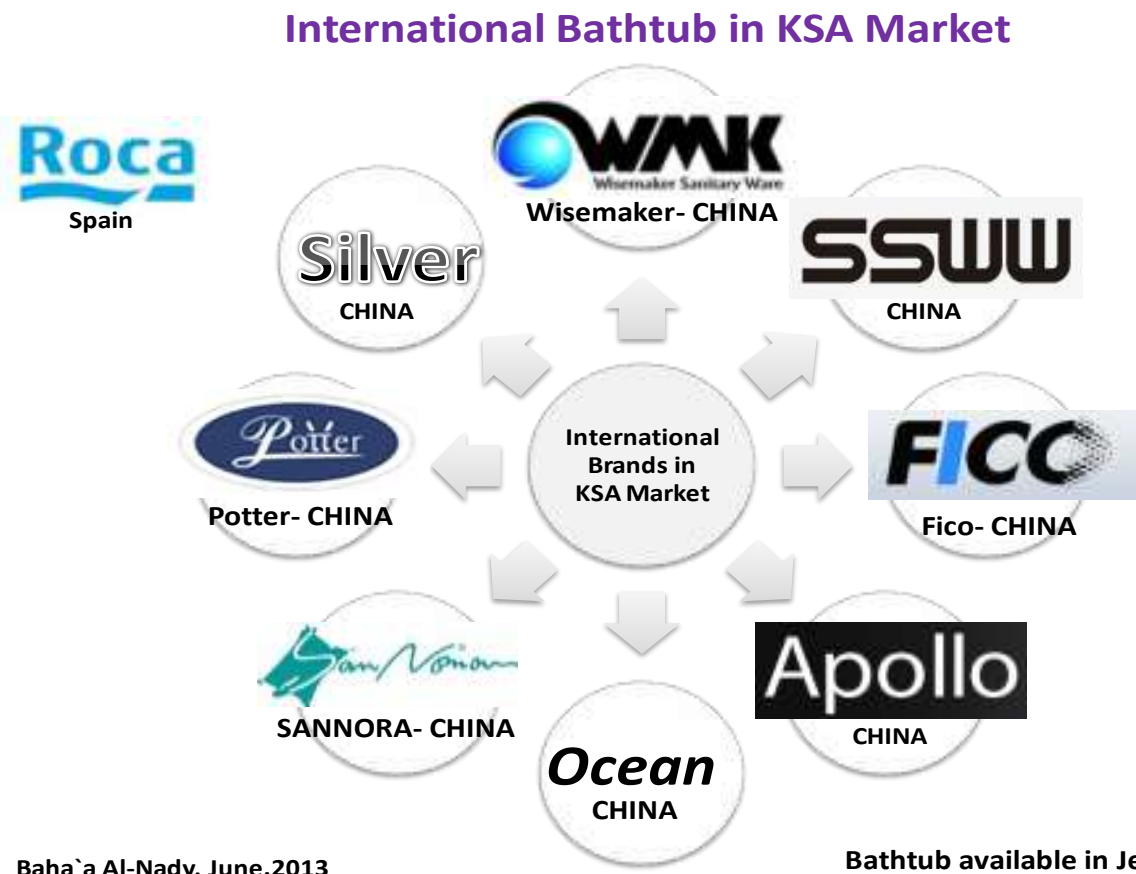

Baha`a Al-Nady, June.2013

Bathtub available in Jeddah City

\section{Author's Biography with photo}

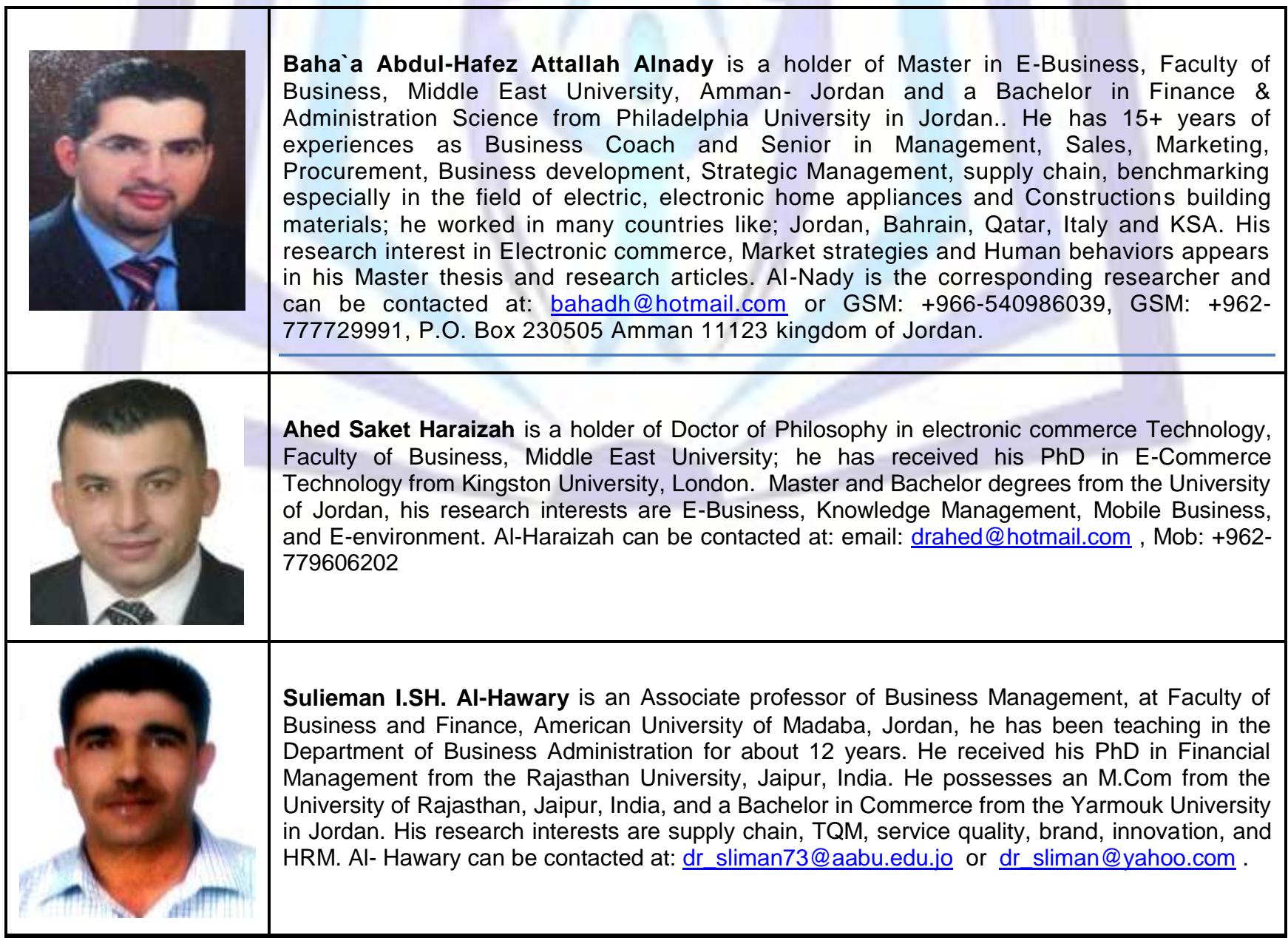

